\title{
Pisanje Slobodne Dalmacije o HRSS-u od 1945. do 1947.
}

\author{
Ivo Mišur ${ }^{\circledR}$ \\ Zagreb \\ ivo.misur@gmail.com
}

SAŽETAK: Komunistička partija Jugoslavije je tijekom Drugoga svjetskog rata nastojala privući i članove prijeratnoga HSS-a te tako omasoviti partizanski pokret. To im je djelomično i uspjelo jer se na oslobođenom partizanskom teritoriju 1943. formirao Izvršni odbor ove stranke. Nakon završetka rata $\mathrm{H}(\mathrm{R}) \mathrm{SS}$ je zajedno s KPJ sudjelovao na izborima u koaliciji Jedinstveni narodno-oslobodilački front (JNOF). U članku će se prikazati kronologija organizacijske obnove stranke u Dalmaciji. Pošto dosad nema objavljenih relevantnih izvora o broju obnovljenih stranačkih mjesnih organizacija, na temelju novinskih izvještaja Slobodne Dalmacije pokušat će se utvrditi geografska rasprostranjenost ogranaka na području Dalmacije. Istražit će se programska autonomija dalmatinskih ogranaka Stranke prezentirana u dnevnom tisku kroz medijske istupe (intervjue i govore) stranačkih prvaka te službene proglase Izvršnoga odbora Stranke u razdoblju od 1945. do 1947. godine. Također će se analizirati stupanj kadrovske te organizacijske ovisnosti HRSS-a u Dalmaciji o KPJ. Provest će se analiza uloge HRSS-a unutar Narodne fronte. Koristit će se dosadašnja objavljena literatura te arhiv Slobodne Dalmacije, tadašnjega službenoga glasila Narodne fronte Dalmacije.

Ključne riječi: Dalmacija; HSS; HRSS; Narodna fronta; izbori 1945.

\section{Uvod}

U proljeće 1941. godine njemačka je vojska napala Kraljevinu Jugoslaviju, a Slavko Kvaternik 10. travnja na radiju proglasio Nezavisnu Državu Hrvatsku. Nekoliko dana poslije Ante Pavelić došao je iz Italije te preuzeo vlast i uspostavio diktaturu. Vrlo su se brzo proglasili rasni zakoni, a dijelovi Dalmacije se Rimskim ugovorima 18. svibnja 1941. ustupili Italiji, što je izazvalo nezadovoljstvo među stanovništvom. Radi ovoga formirao se u ilegali partizanski pokret, predvodnici kojega su bili komunisti. S druge strane, vođa najjače predratne političke stranke - HSS-a - Vladko Maček odlučio se na politiku čekanja. Brojni nezadovoljni članovi stranke odlaze potom u partizane. Na oslobođenom se teritoriju, pod vodstvom Božidara Magovca, 
formirao Izvršni odbor HSS-a koji je izdavao svoje glasilo Slobodni dom. Završetkom rata i pobjedom partizana obnovila se Jugoslavija, a Maček pobjegao u inozemstvo. Kralj Petar, koji je rat proveo u egzilu u Londonu, poslao je Ivana Šubašića, koji je s Titom dogovorio zajedničku vladu te provođenje slobodnih izbora na kojima će narod odlučiti o budućem ustroju države. Komunisti su formirali Narodnu frontu Jugoslavije u koju su nastojali uključiti što je više moguće naizgled različitih političkih opcija, među kojima i obnovljeni HRSS. ${ }^{1}$

Znanstveno istraživanje poslijeratnoga HRSS-a intenzivirano je početkom 1990-ih. Tematiku je temeljito istražio Zdenko Radelić, zaposlenik Instituta za historiju radničkog pokreta (poslije Hrvatski institut za povijest) u Zagrebu. U Časopisu za suvremenu povijest objavio je članke »Uobličavanje uloge Hrvatske republikanske seljačke stranke 1945.-1948.« (23/1991/ 1-3), »Izvršni odbor Hrvatske republikanske seljačke stranke i njegovi otpadnici (1945.-1948.)《(24/1992/ 2), te »Organizacija i osnivačke skupštine odbora Hrvatske republikanske seljačke Stranke 1945.-1947.« (28/1996/ 1-2). Radelić je svoje istraživanje sintetizirao u dvije knjige: Hrvatska seljačka stranka: 1941-1950 (Zagreb 1996) i Božidar Magovac: s Radićem između Mačeka $i$ Hebranga (Zagreb 1999). Temom jugoslavenske poslijeratne demokracije i izbornih procesa bavila se Katarina Spehnjak, objavivši rad »Funkcioniranje „plebiscitarne demokracije“ u Hrvatskoj 1945.-1952. (Izborni aspekt organizacije legitimacijskog procesa)« u Časopisu za suvremenu povijest (23/1991/ 1-3).

Još za vrijeme rata KPJ je nastojao privući pristaše HSS-a u borbu kako bi osigurao masovnost partizanskoga pokreta te povećao vojnu snagu. Stranačka okupljanja i sastanci HSS-ovaca na partizanskom teritoriju počeli su već u kolovozu 1943. godine. Na poticaj Božidara Magovca počeo je izlaziti časopis Slobodni dom. Izvršni odbor HSS-a osnovan je u Plaškom 12. listopada 1943. Stranačka struktura i članstvo bili su nedefinirani. Nitko nije imenovan na mjesta predsjednika, potpredsjednika i tajnika sve do 29. travnja 1944. i sastanka u Taborištu kraj Slunja. Nisu postojali popisi članova, članske iskaznice niti članarina. Nije postojao čak niti statut. Organizacijska struktura stranke odvijala se oko Slobodnog doma. U svakom selu izabran je povjerenik časopisa. Seoski su povjerenici među sobom birali općinske, koji su opet birali kotarske povjerenike. ${ }^{2}$

Na trećem plenumu HSS-a, održanom u lipnju 1945., Izvršni je odbor preimenovao stranku u Hrvatska republikanska seljačka stranka (HRSS). ${ }^{3}$ U rujnu 1945.

1 Zdenko Radelić, »Izvršni odbor Hrvatske republikanske seljačke stranke i njegovi otpadnici (1945.-1948.)« Časopis za suvremenu povijest, 24(1992), 2, str. 59-60.

2 Zdenko Radelić, Hrvatska seljačka stranka: 1941-1950. Zagreb: Hrvatski institut za povijest, 1996. str. 134-136.

3 Zdenko Radelić, »Organizacija i osnivačke skupštine odbora Hrvatske republikanske seljačke Stranke 1945.-1947.«, Časopis za suvremenu povijest, 28(1996) 1-2, str. 73. 
godine planirano je održavanje skupštine HRSS s delegatima iz cijele zemlje. Međutim, od ove se ideje odustalo te je 16. rujna organiziran javni skup, manifestacija na igralištu Concordije. Unatoč svim manjkavostima, službena su glasila skupu pokušavala dati što veći legitimitet te su ga nazivala skupštinom. ${ }^{4} \mathrm{U}$ Zagreb su toga dana došli brojni delegati pa su se već oko osam ujutro ulicama kretale veće skupine ljudi. Tzv. skupština otvorena je hrvatskom pa jugoslavenskom himnom te riječima »vjera u Boga i seljačka sloga«. Pročitan je Titov brzojav skupštini u kojem je, među ostalim, stajalo: »Želim da Hrvatska republikanska seljačka stranka bude snažan stup u Narodnom frontu koji predstavlja veliku tvorevinu narodno-oslobodilačke borbe«. Skupština je poslala brzojavni pozdrav predsjedniku Titu. Javnom aklamacijom, čitanjem rezolucije i povikom mase »Prihvaćamo!« usvojena je rezolucija koja je dala legitimitet politici Izvršnoga odbora Stranke. ${ }^{5}$ Osudila se Mačekova politika tijekom rata te bijeg u inozemstvo. Kao službena politika stranke, jasno se definiralo republikanstvo i podrška Josipu Brozu - Titu kao vođi partizanskoga pokreta. ${ }^{6}$ Tzv. skupština HRSS-a dala je uvid u stvarno stanje podrške novoj stranci, sponzoriranoj od KPJ. Vladimir Bakarić ocijenio je da su komunisti precijenili snagu HRSS-a (»Oni mimo nas nemaju nikakvog izgleda $\ll)^{?}$

U manje od dvije godine nakon završetka rata građani Jugoslavije četiri su puta izlazili na izbore. Najvažniji su bili oni za Ustavotvornu skupštinu Jugoslavije u studenom 1945. Već iduće godine birana je Ustavotvorna skupština NR Hrvatske, a 1947. godine birani su članovi narodnih odbora. U prosincu 1947. godine održani su izbori za Oblasni odbor NO-a Dalmacije.

Ustavotvorni izbori održani 11. studenog imali su sve elemente plebiscitarnosti, tj. davanja masovne podrške već unaprijed određenoj vlasti i politici. ${ }^{8} \mathrm{Na}$ izborima je bilo moguće glasovanje samo za jednu listu - Jedinstvenu narodnooslobodilačku frontu Jugoslavije (JNOF ili skraćeno NF), »šaroliku koaliciju radnika, seljaka« i drugih politički podobnih kandidata. Osnivački kongres Narodne fronte Jugoslavije održao se od 5. do 9. kolovoza 1945. u Beogradu. Prisustvovalo je 1186 delegata koji su usvojili program, statut i izabrali predsjednika Josipa Broza - Tita. ${ }^{9}$ Franjo Gaži,

4 Radelić, »Organizacija i osnivačke skupštine odbora«, str. 77.

5 »16. 9. skupština HRSS-a u Zagrebu«, Slobodna Dalmacija, 16. IX. 1945., str. 1-2.

6 116. 9. skupština HRSS-a u Zagrebu«, Slobodna Dalmacija, 16. IX. 1945., str. 1.

7 Zdenko Radelić, »Uobličavanje uloge Hrvatske republikanske seljačke stranke 1945.-1948.«, Časopis za suvremenu povijest, 23(1991) 1-3, str. 195; Arhiv Instituta za suvremenu povijest (dalje AISP), CK SKH, Zapisnik CK KPH, 21. IX. 1945.

8 Katarina Spehnjak, »Funkcioniranje „plebiscitarne demokracije“ u Hrvatskoj 1945.-1952. (Izborni aspekt organizacije legitimacijskog procesa) u Hrvatskoj 1945.-1952.«, Časopis za suvremenu povijest, 23(1991) 1-3, str. 217.

9 Branko Petranović, »Osnivački kongres Narodnog fronta Jugoslavije«, Časopis za suvremenu povijest, 12(1980) 1, str. 5 . 
predsjednik HRSS-a, izabran je za jednoga od potpredsjednika NF-a. Osim KPJ, sudjelovali su delegati organizacija koje su pristupile Fronti: Republikanska stranka (Aleksa Tomić), Narodna seljačka stranka (Radomir Tadorović), Savez zemljoradnika (Milan Popović), Socijalistička stranka (Pera Rajković), HRSS (Ante Marinović), Antifašistička fronta žena - AFŽ (Vida Tomašić), Ujedinjeni savez antifašističke omladine Jugoslavije - USAOJ (Slavko Komar), Jedinstveni sindikati radnika i namještenika Jugoslavije - JSRNJ (Laza Stefanović). ${ }^{10}$ Statut NF-a predviđao je da unutar Fronte mogu postojati političke grupe i stranke koje su zadržavale svoju individualnost čime se cijeloj fronti davao koalicijski karakter. ${ }^{11}$

Neke opozicijske stranke, poput Jugoslavenske demokratske stranke i Narodne radikalne stranke, proglasile su apstinenciju, smatrajući izborni zakon nepravednim. Kako bi spriječili nisku izlaznost, privremena vlada Demokratske Federativne Jugoslavije izmijenila je izborni zakon i postavila na izbornim mjestima i tzv. kutije bez liste. Dijelu građana kojima je dokazano sudjelovanje u neprijateljskim vojnim jedinicama oduzeto je pravo glasa. Oko sredine rujna u Hrvatskoj je bilo $6 \%$ takvih birača. U Dalmaciji je birača s uskraćenim pravom glasa bilo najviše u okruzima Zadar i Srednja Dalmacija. ${ }^{12}$ U Ustavotvornu skupštinu izabrana su 32 kandidata HRSS-a, od toga šest hrvatskih zastupnika u Skupštini naroda (od 32, što je 19\%), a u Saveznoj skupštini 26 članova (od 86, što je 30\%). ${ }^{13}$

U prvom sazivu Narodnoga sabora Federalne Republike Hrvatske nakon izbora 1946. godine bilo je mnogo predratnih članova HSS-a. Većinu članova Prezidijuma Ustavotvornoga sabora i Vlade Hrvatske ipak su činili komunisti. U Prezidijumu je bilo 14 komunista, a u Vladi osam članova, dok je HRSS imao u Prezidijumu šest, a u Vladi pet članova. Ostali su bili stranački nedefinirani. Franjo Gaži postao je potpredsjednik hrvatske vlade. ${ }^{14}$ Jedini tadašnji članovi novoga HRSS-a bili su Dane Škarica iz Dalmacije i Jerko Zlatarić iz Baranje koji su ujedno bili članovi Izvršnoga odbora Stranke. ${ }^{15}$

10 „Prvi kongres Narodnog fronta Jugoslavije«, Slobodna Dalmacija, 8. 8.1945. str. 1.

${ }^{11}$ Petranović, »Osnivački kongres Narodnog fronta Jugoslavije«, str. 6.

${ }_{12}$ Spehnjak, »Funkcioniranje „plebiscitarne demokracije“«, str. 221; AISP, Izborna komisija CK SKH, 1945., IX, i Zapisnik sjednice CK KPH od 15. rujna 1945.

13 Radelić, „Uobličavanje uloge Hrvatske republikanske seljačke stranke 1945.-1948.«, str. 199; Katarina Spehnjak, »Narodni front Hrvatske 1945. godine, Oslobođenje Hrvatske 1945. godine «, Zbornik Instituta za historiju radničkog pokreta Hrvatske, Zagreb 1986, str. 324-327, 329.

${ }^{14}$ Katarina Spehnjak, »Funkcioniranje „plebiscitarne demokracije“ u Hrvatskoj 1945.-1952. (Izborni aspekt organizacije legitimacijskog procesa) u Hrvatskoj 1945.-1952. «, Casopis za suvremenu povijest, 23(1991) 1-3, str. 230.

15 »Popis osoba predloženih za vijećnike Narodnog sabora Hrvatske«, Slobodna Dalmacija, 1. VIII. 1945., str. 2. 
Lokalni izbori za mjesne, kotarske i gradske narodne odbore provedeni su 1947., 1949., 1950. i 1952. godine. Podatci o izlaznosti i rezultatima lokalnih izbora na državnoj ili republičkoj razini nikada nisu objavljeni niti istraženi. ${ }^{16}$

Aktivnosti Stranke postupno su zamirali, iako je HRSS još formalno postojao na izborima za Sabor NR Hrvatske 1950. godine. Tada je Franjo Gaži pozvao pristaše da izađu na izbore: »Nisu važna imena tih kandidata, kao ni to jesu li oni HRSS-ovci ili Partijci, nego je važno, jesu li ljudi od riječi i djela (...) a najvažnije je to, da sav narod u stopostotku izađe na izbore i manifestira, svoju pripadnost našoj političkoj organizaciji Narodnog fronta, svoju odanost našem političkom i državnom rukovodstvu na čelu s drugom Vladimirom Bakarićem i maršalom Titom «. ${ }^{17}$

Osnovna teza koja će se istražiti u članku jest je li obnovljen HRSS u Dalmaciji bio satelitska stranka KPJ kojom su komunisti nastojali na izborima dobiti potporu seljaka kao najbrojnijega društvenog sloja ili je stranka na ovom području imala određenu programsku autonomiju. Istražit će se pristaše i stranački kandidati HRSS-a na više izbora te njihova uloga u Narodnoj fronti. Analizirat će se kronologija obnove ogranaka u Dalmaciji, kao i druge aktivnosti Stranke. Prikazat će se pisanje Slobodne Dalmacije o HRSS-u, kao i izborne poruke i program kojima su nastupale.

\section{Obnova organizacije HRSS-a u Dalmaciji}

Pred zagrebačku skupštinu HRSS-a održanu 16. rujna po dalmatinskim selima održavane su konferencije i sastanci na kojima su birani delegati. Prosječno je po kotaru birano stotinu delegata ${ }^{18}$ tako da je na skupštini bilo nekoliko tisuća članova. U Makarskoj je prije putovanja stranačkih delegata na skupštinu u Zagreb održan velik skup. ${ }^{19}$ Delegate, među kojima je bilo starih i mladih intelektualaca i seljaka, od kojih su neki putovali u narodnim nošnjama, ispratili su lokalni predstavnici NF-a. ${ }^{20}$

Dva tjedna nakon stranačke skupštine Izvršni je odbor (IO) 5. listopada 1945. poslao upute za organizaciju kotarskih odbora HRSS-a. ${ }^{21}$ Tadašnji članovi IO-a bili

16 Katarina Spehnjak, »Funkcioniranje „plebiscitarne demokracije“«, str. 232.

17 Vjesnik, 11. X. 1950. str.7.

18 »Pristaše HRSS birani na masovnim sastancima odlaze u Zagreb «, Slobodna Dalmacija, 12. IX. 1945., str. 4.

19 »Na zboru u Makarskoj pristaše HRSS osuđuju dr. Mačeka«, Slobodna Dalmacija, 16. IX. 1945., str. 4.

20 »Delegati HRSS biokovsko-neretvanskog okruga otputovali su na svoju skupštinu u Zagreb«, Slobodna Dalmacija, 14. IX. 1945., str. 4.

${ }^{21}$ Radelić. »Organizacija i osnivačke skupštine«, str. 77. 
su Mate Aljinović, Mate Buljan Klapirić, Martin Grubišić, Pavao Krce, Ivan Kuzmić, Marijan Radić, Nikola Sikirica i Martin Sučić. U Slobodnoj Dalmaciji objavljen je poziv članovima i pristašama u Dalmaciji da se obnovi stranačka organizacija. U HRSS su se mogli učlaniti stariji od osamnaest godina i žene. Zabranjeno je učlanjivanje onima koji su se ogriješili o NOP i HRSS. Također »treba da bude za bratstvo i jedinstvo našeg naroda u duhu slavenstva u Narodnom frontu skupa sa Srpskim klubom, Komunističkom partijom «. ${ }^{22}$

Procedura osnivanja stranačkih ogranaka bila je komplicirana. Najprije se izabirao peteročlani inicijativni odbor kotarske organizacije koji su birali poznate pristaše $i$ prvake stranke. Ovaj je odbor imao dužnost sazivanja seoskih sastanaka koji su trebali izabrati stranačke povjerenike koji su pak sačinjavali odbor kotarske organizacije. Inicijativni je odbor birao Privremeni odbor koji je imao obvezu, prema novoj uputi, sazvati sastanke svih pristaša HRSS-a po selima i provesti izbore mjesnih odbora HRSS-a. Novoizabrani predsjednici tih mjesnih organizacija sastajali su se u sjedištu kotara i među sobom birali predsjedništvo odbora kotarske organizacije. Tek nakon ovog izbora prestaje funkcija privremene kotarske organizacije i povjerenika stranke. Član inicijativnog odbora prema uputi može biti »samo seljak od pluga i motike ili takav neseljak fabrinik, trgovac ili intelektualac koji je za vrijeme četirigodišnjeg rata bio otvoreni pristaša Narodno-oslobodilačkog pokreta, u njemu surađivao ili ga ilegalno pomagao, da nije polagao ustašku zakletvu, da nije surađivao s okupatorom ili bilo kojim protunarodnim organizacijama, da je iskreni prijatelj suradnje i radnika. Također pravo biranja povjerenika imaju samo oni pristaše i prvaci HRSS-e, muškarci i žene, koji imaju pravo glasa i koji nisu za vrijeme narodnooslobodilačkog rata iznevjerili program HRSS-a. Povjerenik stranke u selu može biti jedino seljak od pluga i motike«. ${ }^{23}$

Neki ogranci osnovani su prije službenih uputa Stranke, o čemu piše Nikola Sikirica, istaknuti stranački dužnosnik: »One organizacije koje su obnovljene prije tih uputstava stvorene su također u duhu koji provijava u samoj Uputi«. ${ }^{24}$ Zdenko Radelić u svom članku »Organizacija i osnivačke skupštine odbora Hrvatske republikanske seljačke Stranke 1945.-1947.« piše da su se prvi zborovi održali na zadarskom području, ali je prvi inicijativni odbor stranke u Dalmaciji osnovan u Stonu, međutim Slobodna Dalmacija navodi da je konferencija pristaša HRSS-a tamo održana tek krajem listopada. Na njoj je sudjelovao kandidat vezane liste za kotar Korčula-Pelješac Mato Skaramuća. ${ }^{25}$

22 »Poziv svim članovima i pristašama HRSS Dalmacije«, Slobodna Dalmacija, 7. X. 1945., str. 2.

23 »O organizaciji HRSS-a u Srednjoj Dalmaciji«, Slobodna Dalmacija, 27. XI. 1945., str. 3.

24 Isto.

25 Radelić. »Organizacija i osnivačke skupštine«, str. 80; »Kotarska konferencija prvaka i pristaša HRSS-a«, Slobodna Dalmacija, 28. X. 1945., str. 2. 
U Muću je još prije poziva središnjice 4. listopada održana konferencija HRSS-a na kojoj je izabrana kotarska mjesna organizacija. Sedamdeset osam delegata iz dvadeset šest sela izabralo je predsjednika i kotarski izvršni odbor. Prema uhodanoj proceduri skup je otvorio stari HSS-ovac (Marijan Stričević) koji je ukratko prezentirao povijest Stranke, naglasio opredjeljenje za Tita te ukazao na kontinuitet republikanske ideje od Radića do Tita. Maček je prokazan kao izdajnik. ${ }^{26}$

U Trilju je ogranak osnovan 9. listopada. Za predsjednika je izabran Nikola Sikirica, koji je tada obnašao dužnost predsjednika mjesnoga NO-a. ${ }^{27} \mathrm{U}$ kotaru Trilj IO je obnovio stranku u selima: Tijarica, Gornja i Donja Ruda, Udovičići, Košute, Bisko, Vonić, Potinje i Vrpče. Predsjednik ogranka bio je Nikola Sikirica. ${ }^{28}$

U Sinju su 13. listopada Nikola Sikirica i Pavao Krce organizirali sastanak na kojem je izabran odbor od dvanaest članova koji je počeo obnovu stranke u sinjskom kotaru. ${ }^{29} \mathrm{U}$ ovom je kotaru također izabran kotarski izvršni odbor u kojem su svoja mjesta dobili stari pristaše i prvaci seljačke stranke. Za predsjednika je izabran Stipe Efendić. Odbor se obvezao da će obnoviti organizacije Stranke po selima kotara, ali krajem studenoga središnjica Stranke nije imala izvještaja o aktivnosti. ${ }^{30}$

U Imotskom se 14. listopada sastao inicijativni odbor. Na osnivanju je bilo 57 članova ${ }^{31} \mathrm{U}$ novinskoj je vijesti istaknuta informacija da je bio prisutan Ivan-Ban Jukić, predsjednik okružnog NF-a i stranački prvak. Tada je formiran inicijativni odbor od devet članova. U kratkom je vremenu odbor održao sastanke po okolnim selima te je za desetak dana održan sastanak s 57 predstavnika novoizabranih mjesnih organizacija. Za predsjednika kotarskoga ogranka izabran je prijeratni stranački uglednik Stipe Kristić. ${ }^{32}$

Kotarski odbor Vrlika postojao je već 16. listopada, a ogranci su organizirani u selima Podosoje, Garjak, Ježević, Maljkovo, Vinalić, Kijevo, Kosore i u samoj Vrlici. U kotaru je bilo 2516 članova stranke. Predsjednik je bio Ilija Jakelić. ${ }^{33}$ U Vrličkoj je krajini u selima Otišić, Cetina, Koljane i Civljane biran odbor HRSS-a, što je neobično jer je riječ o većinskim pravoslavnim selima u kojima prije rata nije bilo pri-

\footnotetext{
26 »Poziv svim članovima i pristašama HRSS Dalmacije«, Slobodna Dalmacija, 7. X. 1945., str. 2.

27 »Konferencija HRSS u Trilju«, Slobodna Dalmacija, 16. X. 1945., str. 5.

28 »O organizaciji HRSS-a u Srednjoj Dalmaciji«, Slobodna Dalmacija, 27. XI. 1945., str. 3.

29 »Obnavljanje HRSS u sinjskom kotaru«, 17. X. 1945., str. 3.

30 »O organizaciji HRSS-a u Srednjoj Dalmaciji«, Slobodna Dalmacija, 27. XI. 1945., str. 3.

31 »Obnavljanje organizacija HRSS u imotskom kotaru«, Slobodna Dalmacija, 31. X. 1945., str. 2.

32 Isto.

33 »HRSS dat će sve za slogu, bratstvo i jedinstvo naših naroda«, Slobodna Dalmacija, 16. X.
} 1945., str. 5. 
staša HSS-a. ${ }^{34}$ Zanimljivo je da je među stranačkim delegatima iz Vrlike koji su išli na skupštinu u Zagrebu bilo i Srba koji su došli na inzistiranje sumještana hrvatske nacionalnosti. ${ }^{35}$ Pokretač stranke u vrličkom kotaru bio je Ilija Jakelić, ${ }^{36}$ koji je zajedno sa starim radićevcima, Juricom Barišićem i Antom Blaževićem, obnovio tamošnje ogranke. U ogranku Maovice predsjednik je bio Mićo Kujundžić, Podosoje - Ilija Jakelić, Garjak - Ilija Vorlić, Ježević - Tomo Plazonić, Maljkovo - Luka Bilandžić, Vinalić - Ivan Zidar, Kijevo - Ante Tončić, Kosore - Josip Klepo, Vrlika - Jurica Barišić. Za članove su birane i žene. ${ }^{37} \mathrm{U}$ cijelom vrličkom kotaru HRSS-u je pristupilo 2516 članova. ${ }^{38}$

U kotaru Split-Solin stranački pristaše stranke su s predsjednikom Matom Aljinovićem bili aktivni u Vučevici, Bročancu, Konjskom, Koprivnu, Dolcu Donjem, Kotlenici, Kaštel Starom, Kaštel Novom, Kaštel Štafiliću i Stobreču. ${ }^{39}$ Krajem studenog 1945. formirani su inicijativni odbori u kotarima Omiš, Brač, Trogir i Hvar. U ovim kotarima u kojima su formirani inicijativni odbori pristaše još nisu započeli s redovitim radom u obnovi stranačkih ogranaka ${ }^{40}$ U Jelsi na Hvaru se 19. listopada obnovio ogranak, osnivanjem inicijativnog odbora. ${ }^{41}$ Oko 25 . listopada formirani su inicijativni odbori u Šibeniku i Drnišu. Na njima je bio prisutan Ivan Kuzmić. ${ }^{42}$

Ivan Kuzmić je također kao istaknuti stranački dužnosnik 28. listopada nazočio konferenciji pristaša HRSS-a u Dubrovniku na kojem su bili prisutni delegati svih mjesta iz kotara. ${ }^{43} \mathrm{U}$ Dubrovniku je 28 . listopada osnovan ogranak, tj. inicijativni odbor. Sastanku je prisustvovalo 65 delegata iz svih sela kotara ${ }^{44}$ U Stonu je tako-

\section{X. 1945., str. 2 .}

34 »Narod vrličkog kotara glasovanjem će potvrditi tekovine svoje borbe«, Slobodna Dalmacija, str. 3.

35 „Član oblasnog odbora Narodnog fronta Nikola Sikirica«, Slobodna Dalmacija, 10. X. 1945.,

${ }^{36}$ Ilija Jakelić bio je zemljoradnik rođen 1898. godine u Podosojama kod Vrlike. Prijeratni HSS-ovac, 1944. godine pridružio se partizanima. Bio je prvi predsjednik općinskog NO-a Vrlika. Poslije rata postao je član plenuma IO-a HRSS-a i Izvršnog odbora Kotarskog NF-a Sinj: »Kandidati NF-a za Ustavotvorni sabor NRH u oblasti Dalmacija«, Slobodna Dalmacija, 13. X. 1946., str. 1. 1945., str. 1.

37 »Osnivanje organizacija HRSS u okrugu Srednje Dalmacije«, Slobodna Dalmacija, 18. X.

\footnotetext{
${ }^{38}$ Isto.

$39 » O$ organizaciji HRSS-a u Srednjoj Dalmaciji, Slobodna Dalmacija, 27. XI. 1945., str. 3.

${ }^{40}$ Isto.

41 »Obnovljen HRSS u hvarskom kotaru«, Slobodna Dalmacija, 21. X. 1945., str. 1.

42 „Formiranje HRSS u šibenskom okrugu«, Slobodna Dalmacija, 25. X. 1945., str. 4.

43 »zjava Ivana Kuzmića, člana izvršnog odbora HRSS«, Slobodna Dalmacija, 1. XI. 1945., str. 3.

${ }^{44}$ »Konferencija pristaša HRSS dubrovačkog kotara«, Slobodna Dalmacija, 30. X. 1945., str. 3.
} 
đer oko 28. listopada formiran osmeročlani inicijativni odbor koji je pristupio obnovi mjesnih ogranaka. ${ }^{45}$

U selu Mlini, u dubrovačkoj okolici, je početkom studenog 1945. održan sastanak na kojem je smijenjen član mjesnog inicijativnog odbora koji je za vrijeme rata bio zamjenik načelnika gradske općine Dubrovnik te je na taj način prema ocjeni stranke surađivao s okupatorom. ${ }^{46}$ Ivan Kuzmić je u zadnjim danima listopada 1945. posjetio sljedeća naselja u dubrovačkoj okolici: Osojnik, Rijeku Dubrovačku, Mline, Đurinić, Grude, Pridvorje, Ćilipe, Maljkovo, Slano i Orašac u kojima su održane stranačke konferencije. ${ }^{47}$ Dana 13. siječnja 1946. izabran je inicijativni odbor za kotar Korčulu. ${ }^{48} \mathrm{Na}$ užem području grada Dubrovnika aktivnosti stranke ponovno se obnavljaju tek krajem ožujka 1946., kada je održan sastanak simpatizera iz Gruža i Lapada. Istaknuta je potreba da se u rad stranke uključe i žene. Izabran je privremeni odbor od četrnaest osoba. ${ }^{49} \mathrm{U}$ travnju 1946. održan je sastanak pristaša stranke u kotaru Dubrovniku. Na korištenje su im dane prostorije Gradskog odbora. Prisustvovalo je pedeset delegata iz svih mjesta kotara. Na ovom okupljanju izabran je predsjednik privremenog kotarskog inicijativnog odbora. Donesen je zaključak da se u mjestima gdje to dosada nije učinjeno pristupi formiranju mjesnih odbora nakon kojega bi se izabrao stalni kotarski odbor stranke. ${ }^{50}$ Sredinom srpnja 1946. Franjo Gaži posjetio je Dubrovnik. Sastao se s predstavnicima mjesnih stranačkih odbora. Istaknuo je potrebu obnove mjesnih ogranaka te organiziranja smotre Seljačke sloge. ${ }^{51}$ U Dubrovniku je početkom prosinca 1946. izabran Izvršni odbor mjesne organizacije. Također je izabran odbor za aktivizaciju društva Seljačke sloga koji je dobio zadatak da pripremi smotru hrvatske seljačke kulture koja se planirala za svibanj 1947. godine..$^{52}$ Škare je u rujnu 1947. obilazio sela imotskoga i dubrovačkoga kotara s ciljem obnove Seljačke sloge. Na području Dubrovnika osnovana su četiri, a u imotskom kotaru pet ogranaka. ${ }^{33}$

45 »Kotarska konferencija pristaša i prvaka HRSS-a u Stonu«, Slobodna Dalmacija, 28. X. 1945., str. 2 .

46 »Pristaše, HRSS-a u Župi Dubrovačkoj smijenile člana inicijativnog odbora koji je služio okupatoru«, Slobodna Dalmacija, 8. XI. 1945., str. 5.

47 Isto.

48 »Izabran inicijativni odbor HRSS za kotar Korčulu«, Slobodna Dalmacija, 26. I. 1946., str. 4.

49 »Osnovan je privredni odbor Hrvatske republikanske stranke u Gružu«, Slobodna Dalmacija, 16. III. 1946., str. 2.

50 »Aktivnost pristaša HRSS u Dubrovniku«, Slobodna Dalmacija, 20. IV. 1946., str. 3.

51 »Boravak predsjednika HRSS-e i potpredsjednika vlade NR Hrvatske Franje Gažija u Dubrovniku«, Slobodna Dalmacija, 25. VII. 1946., str. 5.

52 »U Dubrovniku je izabran Izvršni odbor mjesne organizacije HRSS «, Slobodna Dalmacija, 9. XII. 1946., str. 4.

53 »Boravak Stanka Škare i tajnika HRSS-a u Dalmaciji«, Slobodna Dalmacija, 18. IX. 1947., str. 2. 
Koristeći se arhivskim izvorima, Radelić spominje da je u drniškom kotaru u svibnju 1946. osnovano 35 mjesnih odbora. ${ }^{54} \mathrm{U}$ kninskom kotaru postojalo je sedam mjesnih odbora, a u planu je bilo osnivanje kotarskoga odbora. U imotskom je kotaru bilo između 43 i 57 mjesnih odbora. U svibnju 1946. postojao je inicijativni odbor stranke u kotaru Metković-Vrgorac. U Sinju je 19. svibnja 1946. osnovan Kotarski odbor HRSS-a. U radu su prilikom osnivanja sudjelovali delegati iz 36 sela. Tako su 31. siječnja 1947. u kotarskom odboru djelovali predstavnici tek 19 mjesta. ${ }^{55} \mathrm{U}$ ljeto 1946. je, prema izvještaju upućenom Centralnom komitetu KPJ, u Hrvatskoj bilo 86 kotarska i 132 mjesna odbora. Na spomenutom je izvještaju činovnik iz CK izrazio sumnju u istinitost podataka te napisao $»$ nemoguće«.$^{56}$ Gaži je sredinom 1946. stranim novinarima tvrdio da HRSS ima 60 kotarskih ogranaka, a da je brojnost članstva kao u doba Radića. ${ }^{57}$ Slobodna Dalmacija, koja je ažurno izvještavala o aktivnostima HRSS-a, nije donosila vijesti o brojnosti ogranaka.

\section{Politički program i izborne poruke HRSS-a}

Stranački dužnosnici HRSS-a, kao i članovi KPJ, još su prije završetka rata HRSS u potpunosti podređivali interesima KPJ. Član izvršnoga odbora JNOF-a, Karlo Mrazović, na sjednici plenuma oblasnoga odbora JNOF-a za Dalmaciju 22. travnja 1945. u svom je govoru, referirajući se na predratnu političku situaciju, kao jedine demokratske snage naveo Komunističku partiju i HRSS. ${ }^{58}$ Izvršni odbor HRSS-a je na sjednici održanoj 29. i 30. lipnja 1945. donio rezoluciju koja je »konstatirala da je u Demokratskoj Federativnoj Jugoslaviji, a zahvaljujući Narodno-oslobodilačkoj borbi, hrvatski narod ostvario svoje vjekovne težnje za nacionalnim oslobođenjem«. Također tada je promijenjeno ime stranke iz HSS u HRSS te je zaključeno da će »Izvršni odbor HRSS-a nastaviti s borbenim radom rame uz rame s Komunističkom partijom, te braćom Srbima i muslimanima u Jedinstvenoj narodno-oslobodilačkoj fronti za ostvarenje radničko-seljačke republike «.$^{59}$ Mate Skaramuća, kandidat vezane liste kotara Korčula-Pelješac u jednom govoru izjavljuje: »Mi obnavljamo Hrvatsku republikansku seljačku stranku kako bi naš NF bio čvršći i jači i izvršio zadatke koji se preda nj postavljaju... Mi nismo komunisti, ali idemo rame uz rame s komuni-

54 Radelić »Organizacija i osnivačke skupštine odbora«, str. 81.

55 Isto.

56 Isto, str. 77; Usp. HDA, Politbiro CK SKH, inv. br. 2135/a, Teze za politički referat.

57 »Izjava predsjednika HRSS Franje Gažija predstavnicima strane štampe u Zagrebu«, Slobodna Dalmacija, 9. X. 1946., str. 4.

58 „Sjednica plenuma oblasnog odbora JNOF-a za Dalmaciju«, Slobodna Dalmacija, 24. IV. 1945., str. 1.

59 »Izvršni odbor HRSS-a osudio izdaju d-ra Mačeka«, Slobodna Dalmacija, 15. VII. 1945., str. 1. 
stima da bismo konačno ostvarili republiku« ${ }^{60}$ HRSS-ovac Ivan Granđa u tijeku izborne kampanje 1946. godine izjavio je: »Najbrojnije su zastupani u Narodnoj fronti Komunistička partija i Hrvatska republikanska seljačka stranka, a mi znamo da su tim strankama temeline ideje socijalne pravice, pa prema tome je prvenstvena dužnost i pristaša tih najvećih organizacija Narodne fronte da budno paze da u narodne odbore budu izabrani ljudi pravedni i pošteni, koji su odani narodu i njegovoj vlasti «. ${ }^{11}$ Pavao Krce, koji se na izborima 1946. godine kandidirao u sinjskom kotaru za Ustavotvorni sabor Hrvatske, iste godine izjavljuje: »Moram vam odmah naglasiti da HRSS ima jednaka prava sa drugim strankama koje sudjeluju u Narodnom frontu $\ll^{62}$

Još za vrijeme rata lojalnost Mačeku, odnosno odricanje od njegove politike, bila je linija razgraničenja kojom je KPJ dijelila HSS-ovce. ${ }^{63}$ U govorima stranačkih predstavnika predsjednik KPJ Josip Broz - Tito predstavljan je kao jedini ideološki nasljednik Stjepana Radića. Predsjednik NF-a u Hvaru je prisustvovao osnivačkoj skupštini HRSS-a. U svom je govoru iznio povijest stranke te izdajnički rad dr. Mačeka: »Dužnost je svakog pravog pristaše ideje braće Radića, da preko svoje organizacije ojača narodni front te na taj način pospješi ostvarenje ideala braće Radić«. ${ }^{64}$ Kontinuitet Radićeva nauka u NF-u konstantno se naglašavao: »Mi Hrvati, članovi HRSS samo u ovoj borbi pod mudrim vodstvom maršala Tita možemo ostvariti u cjelini program HRSS po nauci braće Radića ${ }^{65}$ ili $»$ Pristaše HRSS su dosljedni nauci braće Radić i glasovat će za Republiku« ${ }^{66}$

Ulazak u odbore stranke strogo se kontrolirao te je političko djelovanje omogućeno samo pojedincima odanima idejama NF-a. Ivan Kuzmić je 1. siječnja 1946. u Slobodnoj Dalmaciji objavio članak u kojem je dao pregled rada i smjernice za daljnji rad i organizacije HRSS-a, pojasnivši motive komplicirane i dugotrajne procedure obnove mjesnih organizacija: »organizirati kotarske inicijativne odbore, čija je dužnost organizirati mjesne organizacije, ali prethodno izvršiti temeljito čišćenje u stranci. Stvarati prema potrebi stranačke povjerenike, koji će nanovo vršiti upisivanje u stranku, u koju ne smije doći ni jedan od onih koji je u bilo kakvom smjeru

60 „Govor Mate Skaramuća kandidata vezane liste izbornog kotara Korčula-Pelješac«, Slobodna Dalmacija, 4. XI. 1945., str. 3.

${ }^{61}$ Seljačka sloga, (1947) 4, str. 35.

62 »Glasajući za Ustavotvorni sabor, hrvatski narod glasa za slobodu, Republiku i bratstvo«, Slobodna Dalmacija, 10. X. 1946., str. 2.

${ }^{63}$ Radelić, »Uobličavanje uloge Hrvatske republikanske seljačke stranke 1945.-1948.«, str. 181.

64 „Obnavljanje HRSS-a u hvarskom kotaru«, Slobodna Dalmacija, 21. X. 1945., str. 1.

65 »Nestalo je straha i mraka«, Slobodna Dalmacija, 21. X. 1945., str. 2.

66 Isto. 
pomagao ili simpatizirao okupatore ... u ovome poslu postignuti su veliki rezultati, organizirani su odbori u svim kotarevima ${ }^{67}{ }^{67}$ Kuzmić nakon izbora piše sljedeće: \Tko nije za jedinstveni front, taj nije za bratstvo i jedinstvo, za trajan mir i za sredjeniji život naših naroda. Takove treba ispravljati, a ako se to ne može, onda ih treba žigosati i osuditi ${ }^{68}$

Nedostatak političke vizije i plana daljnjeg političkog djelovanja nakon izbora vidljiv je u medijskim istupima stranačkih prvaka. Djelatnost stranke nakon izbora vidi se kroz prosvjetno-društvene aktivnosti. Daljnje aktivnosti stranke sastojale bi se od organizacije tečajeva učenja i pisanja. Organizacije zajedničkih čitanja »novina ili brošura iz naše literature. Udarničkim radom treba organizirati zajedničku obradu zemlje ...organiziranjem zadruga. U svakom selu organizirati proizvođačku zadrugu. Posvetiti pažnju pošumljavanju $\ll^{69} \mathrm{HRSS}$ u potpunosti podržava politiku vodeće stranke KPJ-a. Tako Kuzmić u ljeto 1946. podržava agrarnu reformu i nacionalizaciju. ${ }^{70}$

HRSS i KPJ imali su zajednički program i nastup na izborima. Također je postojala velika kadrovska isprepletenost između dviju stranaka u kojoj su komunisti bili članovi HRSS i obratno. ${ }^{71}$ Bakarić je u listopadu 1946. pred izbore za sabor NR Hrvatske u jednom intervjuu izjavio: »Danas se često puta ne može točno odrediti gdje prestaje uticaj Komunističke partije, a počinje uticaj HRSS-a. Tako je u širokim narodnim masama. Mislim, da će izbori još više učvrstiti tu postojeću suradnju «. ${ }^{72}$ Članstvo HRSS-a međusobno se prožima s KPJ, ali i s drugim partnerima iz NF-a. U Splitu je npr. 6. studenog na skupu AFŽ-a govor održala Anica Roje, istaknuta HRSS-ovka. ${ }^{73}$ Valja spomenuti da je među izbornima kandidatima bilo dosta predratnih članova HSS-a koji nisu postali članovi novoga HRSS-a te su se u NF uključili kao članovi KPJ kao npr. Bernard Stulli. ${ }^{74}$ Još je zanimljiviji podatak da su mnogi HRSS-ovci, pa i brojni članovi IO-a HRSS-a, bili ujedno članovi KPJ (npr. Mate Aljinović, Ilija Jakelić, Pavao Krce, Nikola Sikirica, Mate Sučić i drugi). ${ }^{75}$

67 »Pregled rada i smjernice za daljnji rad i organizacije HRSS-a«, Slobodna Dalmacija, 1. I. 1946., str. 4.

68 Isto.

69 Isto.

70 »11. lipnja - rođendan braće Radić«, Slobodna Dalmacija, 11. VI. 1946., str. 1.

71 Radelić, »Uobličavanje uloge Hrvatske republikanske seljačke stranke 1945.-1948«, str. 205.

72 Vjesnik, 10. X. 1946., str. 7.

73 »Govor Anice Roje, članice HRSS-e«, Slobodna Dalmacija, 6. XI. 1945., str. 2.

74 »Kandidati NF-a za Ustavotvorni sabor NRH u oblasti Dalmacije«, Slobodna Dalmacija, 23. X. 1946., str. 2.

75 Radelić, Hrvatska seljačka stranka: 1941-1950. Zagreb: Hrvatski institut za povijest, 1996., str. 160 i 225. 
Pojedinci unutar KPJ pribojavali su se da obnovljenu organizaciju HRSS-a preuzmu ljudi neskloni KPJ te da ju odvoje od NF-a čime bi se stvorila stvarna oporba koja bi ugrozila partijske interese u borbi za vlast. Ova je opasnost bila najrealnija na području kotara Drniš i Imotski. Tamo su na jednom od sastanaka NF-a neki HSS-ovci doveli u pitanje Partijin primat unutar Fronta. Tako je zabilježena izjava: »HRSS ima mase, a ne Partija, prema tome bi trebala i vlast da bude u rukama HRSS-a, a ne u K. P.巛. ${ }^{76}$

Tijekom 1946. godine dolazi i do medijske marginalizacije HSS-a u službenim glasilima NF-a. Ime stranke rijetko se spominje i u govorima javnih dužnosnika i visokih političara. ${ }^{77}$ Nakon postupne obustave političke aktivnosti ubrzo je stranačko glasilo izgubilo prepoznatljivost te su uklonjeni stranački simboli. Početkom 1948. godine iz zaglavlja časopisa Slobodnoga doma uklonjen je slogan »Vjera u boga i seljačka sloga«. Ubrzo je časopis prestao obilježavati i čitateljima čestitati vjerske blagdane ${ }^{78} \mathrm{U}$ internim dokumentima NF-a članovi se još do 1949. godine dijele po stranačkoj pripadnosti. Na 2. kongresu NF-a Hrvatske, održanog 23. do 24. I. 1949. godine, među članovima Izvršnoga odbora Narodne fronte Hrvatske bilo je dvanaest HRSS-ovaca, što je $19,67 \%{ }^{79}$

\section{Zaključak}

Tijekom Drugoga svjetskog rata na području koje su kontrolirali partizani formirao se izvršni odbor disidentskog HSS-a koji se protivio politici legitimnoga predsjednika stranke Vladka Mačeka. Nakon završetka rata i njegova bijega iz zemlje ovaj HSS ostaje jedini u Jugoslaviji te brzo mijenja ime u HRSS. Ova stranka je na poslijeratnim izborima ušla u široku koaliciju Narodne fronte koju je predvodio KPJ. Valja naglasiti da se tadašnji HRSS može samo uvjetno nazivati strankom jer je od samih početaka u izvršnom odboru prevladala struja koja se u korist KP-a odrekla vlastite stranačke autonomnosti. ${ }^{80}$ Početkom listopada 1945., samo mjesec dana prije izbora za Ustavotvornu skupštinu, počinje obnova stranačkih mjesnih ogranaka. Osnivanje ogranaka HRSS-a potiču drugi predstavnici NF-a. Pošto se HRSS nalazio unutar NF-a, ne može se utvrditi kakav je izborni rezultat ostvario.

76 Radelić, »Uobličavanje uloge Hrvatske republikanske seljačke stranke 1945.-1948.«. str. 206; AISP, CK SKH, i.b. str. 337, Izvješće OK KPH Dalmacija, XI. 1946.

77 Radelić, »Uobličavanje uloge Hrvatske republikanske seljačke stranke 1945.-1948«, str. 212.

78 Lydia Sklevicky, »Nova godina - od „Mladog ljeta“ k političkom ritualu«, Etnološka tribina, 11(1988), str. 59-72.

79 Radelić, »Uobličavanje uloge Hrvatske republikanske seljačke stranke 1945.-1948.«, str. 212; Katarina Spehnjak, »Organiziranost i oblici djelovanja Narodnog fronta Hrvatske 1945-1953. godine«, Povijesni prilozi, 6(1987) 6, str. 39.

80 Radelić, Hrvatska seljačka stranka: 1941-1950., Zagreb: Hrvatski institut za povijest, 1996., str. 132. 
Poruke se na izbornim mitinzima te osnivačkim skupštinama ogranaka ponavljaju. Političari nemaju konkretan program, već se izbori svode na izbor između republike, Tita, Narodne fronte, NOB-a, braće Radić te monarhije, kralja, okupatora i Mačeka s druge strane, kao njihovih antipoda i »nenarodnih elemenata«. Vijesti o osnivanju ogranaka HRSS-a također su suhoparne te se u njima ponavljaju iste poruke. Istaknuti predratni stranački prvaci (»stari radićevci«) bili su propagandno iskorišteni u počecima obnove, ali je zamjetan izostanak njihove daljnje aktivnosti u radu stranke. Tuzemni HRSS su nakon rata vodili kadrovi koji su interese stranke podredili interesima NF-a odnosno KPJ.

Obnova mjesnih organizacija zapravo je bila trostruka. Najprije bi se formirao inicijativni, pa privremeni i tek nakon toga bi se birali članovi stalnoga kotarskoga odbora. Početni izbor članova inicijativnih odbora nije bio demokratski jer su ih odabirali stranački prvaci. Nemoguće je govoriti o brojnosti ogranaka jer izvještaji često ne spominju o kojoj je fazi obnove riječ. Izvještaji slani KPJ preuveličavaju stvarni broj obnovljenih ogranaka.

Iz novinskih izvještaja može se zaključiti da je obnova ogranaka finalizirana do osnutka kotarskih ogranaka na području kotara Vrlika, Sinj, Trilj, Solin, Korčula, Dubrovnik i Hvar. Najmasovniji odaziv zabilježen je u Vrlici. U ovom kotaru su u svim mjestima obnovljeni stranački ogranci, a HRSS-u je pristupilo 2516 članova.

HRSS je bio instrumentaliziran od KPJ kako bi se ostvario dobar izborni rezultat u krajevima koji nisu bili skloni komunistima. Stranačko je vodstvo zatomljivalo bilo kakvu autonomiju stranke te je cjelokupnu organizaciju podredilo interesima Narodne fronte odnosno posredno KPJ. Kadrovska isprepletenost s KPJ te nedostatak vlastitoga političkog programa i inicijative te bilo kakve kritike prema vlasti uzrokovala je pad podrške.

Prema svemu sudeći, HRSS je članove i podršku privukao samo svojim imenom, tj. političkim brendom, ugledom koji je uživao prije rata. Slab odaziv na učlanjivanje u stranku daje naslutiti da nije bilo masovnije podrške novom HRSS-u. Razočaranje novim vođama i politikom stranke uzrokovalo je daljnji pad ionako slabe podrške i zamiranje stranačke organizacije. Nedostatak interesa KPJ krajem 1940-ih daje naslutiti da je podrška HRSS-u bila neznatna te da je politička potreba za izdvojenom strankom koja bi predstavljala hrvatske seljake nestala. 


\section{LITERATURA I IZVORI}

Petranović, Branko: »Osnivački kongres Narodnog fronta Jugoslavije«, Časopis za suvremenu povijest, 12(1980) 1, str. 5.

Radelić, Zdenko: »Uobličavanje uloge Hrvatske republikanske seljačke stranke 1945.-1948.«., Časopis za suvremenu povijest, 23(1991) 1-3, str. 195.

Radelić, Zdenko: »Izvršni odbor Hrvatske republikanske seljačke stranke i njegovi otpadnici (1945.1948.).« Časopis za suvremenu povijest, 24(1992), 2.

Radelić, Zdenko: Hrvatska seljačka stranka: 1941-1950. Zagreb: Hrvatski institut za povijest, 1996., str. 134-136.

Radelić, Zdenko: »Organizacija i osnivačke skupštine odbora Hrvatske republikanske seljačke Stranke 1945.-1947.«, Časopis za suvremenu povijest, 28(1996) 1-2.

Sklevicky, Lydia: »Nova godina - od „Mladog ljeta“ k političkom ritualu«, Etnološka tribina, 11(1988), str. 59-72.

Spehnjak, Katarina: »Narodni front Hrvatske 1945. godine, Oslobođenje Hrvatske 1945. godine«, Zbornik Instituta za historiju radničkog pokreta Hrvatske, Zagreb 1986, str. 324-327, 329.

Spehnjak, Katarina: Organiziranost i oblici djelovanja Narodnog fronta Hrvatske 1945-1953. godine«, Povijesni prilozi, 6(1987) 6, str. 39.

Spehnjak, Katarina: »Funkcioniranje „plebiscitarne demokracije“ u Hrvatskoj 1945.-1952. (Izborni aspekt organizacije legitimacijskog procesa) u Hrvatskoj 1945.-1952.«, Časopis za suvremenu povijest, 23(1991) 1-3, str. 217.

»11. lipnja - rođendan braće Radić«, Slobodna Dalmacija, 11. VI. 1946., str. 1.

»16. 9 skupština HRSS-a u Zagrebu«, Slobodna Dalmacija, 16. IX. 1945., str. 1-2.

»Aktivnost pristaša HRSS u Dubrovniku«, Slobodna Dalmacija, 20. IV. 1946., str. 3.

»Boravak predsjednika HRSS-e i potpredsjednika vlade NR Hrvatske Franje Gažija u Dubrovniku«, Slobodna Dalmacija, 25. VII. 1946., str. 5.

»Boravak Stanka Škare i tajnika HRSS-a u Dalmaciji«, Slobodna Dalmacija, 18. IX. 1947., str. 2.

»Član oblasnog odbora Narodnog fronta Nikola Sikirica«, Slobodna Dalmacija, 10. X. 1945., str. 3.

»Delegati HRSS biokovsko-neretvanskog okruga otputovali su na svoju skupštinu u Zagreb«, Slobodna Dalmacija, 14. IX. 1945., str. 4.

»Formiranje HRSS u šibenskom okrugu«, Slobodna Dalmacija, 25. X. 1945., str. 4.

»Glasajući za Ustavotvorni sabor, hrvatski narod glasa za slobodu, Republiku i bratstvo«, Slobodna Dalmacija, 10. X. 1946., str. 2.

»Govor Anice Roje, članice HRSS-e«, Slobodna Dalmacija, 6. XI. 1945., str. 2.

„Govor Mate Skaramuća kandidata vezane liste izbornog kotara Korčula-Pelješac«, Slobodna Dalmacija, 4. XI. 1945., str. 3.

»HRSS dat će sve za slogu, bratstvo i jedinstvo naših naroda«, Slobodna Dalmacija, 16. X. 1945., str. 5.

»Izabran inicijativni odbor HRSS za kotar Korčulu«, Slobodna Dalmacija, 26. I. 1946., str. 4.

»Izjava Ivana Kuzmića, člana izvršnog odbora HRSS«, Slobodna Dalmacija, 1. XI. 1945., str. 3.

»Izjava predsjednika HRSS Franje Gažija predstavnicima strane štampe u Zagrebu«, Slobodna Dalmacija, 9. X. 1946., str. 4.

»Izvršni odbor HRSS-a osudio izdaju d-ra Mačeka«, Slobodna Dalmacija, 15. VII. 1945., str. 1.

»Kandidati NF-a za Ustavotvorni sabor NRH u oblasti Dalmacija», Slobodna Dalmacija, 13. X. 1946., str. 1.

»Kandidati NF-a za Ustavotvorni sabor NRH u oblasti Dalmacije«, Slobodna Dalmacija, 23. X. 1946., str. 2. 
»Konferencija HRSS u Trilju«, Slobodna Dalmacija, 16. X. 1945., str. 5.

»Konferencija pristaša HRSS dubrovačkog kotara«, Slobodna Dalmacija, 30. X. 1945., str. 3.

»Kotarska konferencija pristaša i prvaka HRSS-a u Stonu«, Slobodna Dalmacija, 28. X. 1945., str. 2.

»Na zboru u Makarskoj pristaše HRSS osuđuju dr. Mačeka«, Slobodna Dalmacija, 16. IX. 1945., str. 4.

»Narod vrličkog kotara glasovanjem će potvrditi tekovine svoje borbe«, Slobodna Dalmacija, 12. X. 1945., str. 2.

»Nestalo je straha i mraka«, Slobodna Dalmacija, 21. X. 1945., str. 2.

»O organizaciji HRSS-a u Srednjoj Dalmaciji«, Slobodna Dalmacija, 27. XI. 1945., str. 3.

»Obnavljanje HRSS u sinjskom kotaru«, 17. X. 1945., str. 3.

»Obnavljanje organizacija HRSS u imotskom kotaru«, Slobodna Dalmacija, 31. X. 1945., str. 2.

»Obnovljen HRSS u hvarskom kotaru«, Slobodna Dalmacija, 21. X. 1945., str. 1.

»Osnivanje organizacija HRSS u okrugu Srednje Dalmacije«, Slobodna Dalmacija, 18. X. 1945., str. 1.

»Osnovan je privredni odbor Hrvatske republikanske stranke u Gružu«, Slobodna Dalmacija, 16. III. 1946., str. 2.

»Popis osoba predloženih za vijećnike Narodnog sabora Hrvatske«, Slobodna Dalmacija, 1. VIII. 1945. str. 2.

»Poziv svim članovima i pristašama HRSS Dalmacije«, Slobodna Dalmacija, 7. X. 1945., str. 2.

»Pregled rada i smjernice za daljnji rad i organizacije HRSS-a«, Slobodna Dalmacija, 1. I. 1946., str. 4.

»Pristaše HRSS birani na masovnim sastancima odlaze u Zagreb«, Slobodna Dalmacija, 12. IX. 1945., str. 4.

»Pristaše, HRSS-a u Župi Dubrovačkoj smijenile člana inicijativnog odbora koji je služio okupatoru«, Slobodna Dalmacija, 8. XI. 1945., str. 5.

Seljačka sloga, (1947) 4, str. 35.

„Sjednica plenuma oblasnog odbora JNOF-a za Dalmaciju«, Slobodna Dalmacija, 24. IV. 1945., str. 1.

»U Dubrovniku je izabran Izvršni odbor mjesne organizacije HRSS«, Slobodna Dalmacija, 9. XII. 1946., str. 4.

Vjesnik, 10. X. 1946., str. 7.

Vjesnik, 11. X. 1950., str. 7. 
ARTICLES ABOUT THE HRSS IN SLOBODNA DALM ACIfA FROM 1945. UNTIL 1947.

\author{
Ivo Mišur \\ Zagreb \\ ivo.misur@gmail.com
}

\begin{abstract}
During World War II, the Communist Party of Yugoslavia (CPY) tried to attract members of the pre-war Croatian Peasant Party (HSS) and thus expand the Partisan movement among the masses. They succeeded in part because the HSS Executive Board was formed in the liberated Partisan territory in 1943. After the end of the war, the Croatian Republican Peasant Party (HRSS), together with the CPY, participated in the elections as the United People's Liberation Front (JNOF) coalition. The CPY encouraged the establishment of HRSS branches. Thus, the party planned to achieve a good election result in areas that were not in its favour. The article will present the chronology of the party's organisational renewal in Dalmatia. No relevant sources on the number of renewed local party organisations have been published so far. Based on the information from newspaper reports, membership statistics of party branches in Dalmatia are presented. The programmatic autonomy of the party's Dalmatian branches, presented in the daily press through media appearances (interviews and speeches) of party leaders and official proclamations of the party's Executive Board in the period from 1945 to 1947, is explored. The degree of personnel and organisational dependence of the HRSS in Dalmatia on the CPY is also analysed. An analysis of the role of the HRSS within the Popular Front is conducted. The previously published literature on the HRSS and the archives of Slobodna Dalmacija, the then official gazette of the People's Front of Dalmatia, was used.
\end{abstract}

Keywords: HSS; Dalmatia; communism; elections 1945; HRSS 